\title{
EFFECT OF CYPROTERONE ACETATE ON SPERM CONCENTRATION, SEMINAL FLUID VOLUME, TESTICULAR CYTOLOGY AND LEVELS OF PLASMA AND URINARY ICSH, FSH AND TESTOSTERONE IN NORMAL MEN
}

\author{
H. G. MORSE, D. R. LEACH, M. J. ROWLEY AND \\ C. G. HELLER \\ Division of Reproductive Physiology, Pacific Northwest Research Foundation, \\ 1102 Columbia Street, Seattle, Washington 98104, U.S.A.
}

(Received 31st December 1971)

\begin{abstract}
Summary. Cyproterone acetate (CA) was administered in a dose of $200 \mathrm{mg} /$ day to six normal men for a period of 16 to 20 weeks. A striking reduction in sperm count, libido and potency was observed, while moderate decreases were detected in testicular germ cell numbers, and testosterone levels in both plasma and urine. No significant change was seen in levels of plasma or urinary ICSH, FSH or in Leydig cell morphology or number. It is concluded that CA is acting directly or indirectly upon the seminiferous tubules to produce a decrease in spermatogenesis which, at least partially, explains the dramatic drop in ejaculate sperm concentration. The observed drop in plasma and urinary testosterone levels was not accompanied by a concomitant drop in plasma or urinary ICSH or Leydig cell number. This could result from an inhibition in testosterone secretion by the action of CA.
\end{abstract}

\section{INTRODUCTION}

Cyproterone acetate (CA) is capable of inhibiting the action of androgen directly and locally at target organs in laboratory animals (Bridge \& Scott, 1964; Neumann \& von Berswordt-Wallrabe, 1966; Woolman \& Hamilton, 1968). In animals, this action can result in feminization of male fetuses (Hamada, Neumann \& Junkmann, 1963; Neumann \& Elger, 1966a; Neumann, Elger \& Kramer, 1966), reduction in size and function of accessory sexual glands (Neumann \& von Berswordt-Wallrabe, 1966; Scott \& Schirmer, 1966; Neri, Monahan, Meyer, Afonso \& Tabachnick, 1967; Beach \& Westbrook, 1968; Whalen \& Edwards, 1969; Edwards, 1970), a decrease in sebaceous gland volume (Neumann \& Elger, 1966b), an inhibition of spermatogenesis (Junkmann \& Neumann, 1964; Neumann, Richter \& Guenzel, 1965; Neumann \& von Berswordt-Wallrabe, 1966; Neumann, von Berswordt-Wallrabe, Elger, Steinbeck, Hahn \& Kramer, 1970) and abolition of fertility (Steinbeck, Mehring \& Neumann, 1971). No significant change has been detected in 
mating behaviour of sexually experienced males (Zucker, 1966; Beach \& Westbrook, 1968; Whalen \& Edwards, 1969; Whalen \& Luttage, 1969), running activity (Stern \& Murphy, 1971) or aggression (Edwards, 1970). Testicular interstitial cells of the rat and rabbit have been reported to remain unchanged (Junkmann \& Neumann, 1964; Neumann et al., 1965; Neumann, Elger, von Berswordt-Wallrabe \& Kramer, 1966; Neumann, Elger, von Berswordt-Wallrabe, 1967; Beach \& Westbrook, 1968; Neumann, Elger, Steinbeck \& von Berswordt-Wallrabe, 1968; Neumann et al., 1970), or to increase in diameter in the rat (Goslar, Mehring \& Neumann, 1970; Heinert \& Taubert, 1971).

In man, CA is reported to reduce libido and potency in higher doses (Laschet, Laschet, Fetzner, Glaesel, Mall \& Naab, 1967; Ott \& Hoffet, 1968), inhibit spermatogenesis (Ott \& Hoffet, 1968; Markewitz, Veenema, Fingerhut, Nehme-Haily \& Sommers, 1969; Petry, Mauss, Senge \& Rausch-Stroomann, 1970), and alleviate the symptoms of prostatic carcinoma without the disadvantages of castration or the occurrence of gynaecomastia (Scott \& Schirmer, 1966; Geller, Vazakas, Fruchtman, Newman, Nakao \& Loh, 1968; Scott \& Wade, 1969).

Because it is hazardous to extrapolate to man the large body of data evolved from animal experiments, our objective was to study the mechanism of action of CA upon the reproductive system of normal men. The usual dose of CA is about $200 \mathrm{mg} /$ day (to treat benign or malignant prostatic hypertrophy). It was decided to use the same dose with normal men to obtain an overall view of its effects on seminal fluid volume, sperm concentration, Leydig-cell and germcell numbers, and reproductive hormone concentrations.

If it is true in man, as it apparently is with animals, that CA can reduce fertility without reducing libido or potency (Whalen \& Luttage, 1969), then a suitable dose might be found which would serve as a male contraceptive.

\section{MATERIALS AND METHODS}

The six subjects in this study were healthy, normal male volunteers between the ages of 23 and 41 years. Judging from testicular biopsy morphology, sperm count, sperm morphology and assay of ICSH, FSH and testosterone, all subjects were reproductively normal.

Routine clinical tests were evaluated before and during CA administration, including blood cytology, urinalysis, plasma calcium, inorganic phosphate, glucose, blood urea nitrogen, uric acid, cholesterol, total protein, albumin, total bilirubin, alkaline phosphatase, lactic dehydrogenase and serum glutamic oxaloacetic transaminase.

Cyproterone acetate (6-chloro-17-hydroxy- $1 \alpha-2 \alpha$-methylenepregna-4,6-diene3,20-dione acetate; $\mathrm{SH} 714$ ) was administered orally in a dose of $100 \mathrm{mg}$ twice daily $(200 \mathrm{mg} / \mathrm{day})$. The drug was administered continuously for 16 to 20 weeks. Masturbated semen specimens were collected weekly except when unavailable due to emission in the previous $72 \mathrm{hr}$ or lack of potency. Specimens were examined for sperm concentration, motility and volume. Sperm concentration was determined using a haemocytometer and samples were randomly 
re-examined for accuracy of counts. Sperm morphology was evaluated on 'blinded' specimens by Dr John MacLeod of Cornell University Medical College according to a method previously described (MacLeod, 1962).

Testicular biopsies were taken 1 to 11 months before CA administration (control), after $3 \frac{1}{2}$ to $4 \frac{1}{2}$ months of CA administration (administration), and in three subjects, $6 \frac{1}{2}$ or 10 months after discontinuation of the drug (recovery). These tissues were surgically removed, fixed in Cleland's fixative and stained with iron haematoxylin and eosin using the method of Rowley \& Heller (1966). Germinal cells were quantified from masked slides using the method of Rowley \& Heller (1971). In this method, cells were identified according to the criteria of Clermont (1963) and Heller \& Clermont (1964). Only those cells cut approximately through the centre of the nucleus were counted so that no correction factor was needed to compensate for cell size. All germinal and Sertoli cells meeting these requirements were counted in thirty cross or longitudinally sectioned tubules. The relative number of each type of germinal cell was expressed as the ratio:

No. of germ cells

No. of Sertoli cells

and is referred to as the 'Sertoli cell ratio'. A germ cell was regarded as abnormal if it appeared to be multinucleate, extra large, or had a pycnotic, degenerate or odd-shaped nucleus.

Leydig cells were quantified according to the method of Heller, Lalli, Pearson \& Leach (1971). This method involves counting all Leydig cell and Sertoli cell nucleoli from a minimum of ten randomly selected areas ten $4-\mu \mathrm{m}$ sections apart in the biopsy specimen. These counts are then expressed as the ratio:

No. of Leydig cells

No. of Sertoli cells

Plasma FSH, ICSH and testosterone were assayed from blood samples taken during the control, CA administration and post-administration periods. Plasma FSH was measured using the method of Odell, Parlow, Cargille \& Ross (1968). Plasma ICSH was measured by the method of Odell, Ross \& Rayford (1967). Results were reported as $\mu \mathrm{g}$ standard/100 ml (radioimmunoassay; LER-907standard). Plasma testosterone was measured using the method of Murphy (1970) and reported in $\mathrm{ng} / 100 \mathrm{ml}$.

Eight consecutive 12-hr (overnight) urine samples were collected during the control period, during the CA administration period and during the postadministration period. Urinary FSH, ICSH and testosterone determinations were performed on aliquots of the 8-day pooled specimens. Urine was stored below $5^{\circ} \mathrm{C}$ until the procedures were carried out.

Urinary gonadotrophins were extracted according to the kaolin-acetone method of Albert (1955). Follicle-stimulating hormone was determined by the Steelman \& Pohley (1953) method. Interstitial cell-stimulating hormone was determined using the increase in ventral prostate weights of 21-day-old hypophysectomized rats (Greep, Van Dyke \& Chow, 1941). Urinary FSH and ICSH 
were expressed as $\mathrm{mg} / 24 \mathrm{hr}$ of a standard human urinary postmenopausal preparation (Pergonal P-26e). The urinary gonadotrophins were analysed statistically by the method of Thorslund \& Paulsen (1963). Urinary testosterone and epitestosterone were extracted and analysed using a gas-liquid chromatographic method (Brusca, Kastella \& Heller, 1966) and reported separately as $\mu \mathrm{g} / 24 \mathrm{hr}$.

All results were analysed using Student's $t$ test. For this report, $P \leqslant 0.05$ was the criterion used for statistical significance.

\section{Effect on seminal fluid}

\section{RESULTS}

Sperm concentrations changed with considerable uniformity among the six subjects and were similar to those shown in Text-fig. 1 for Subject 263. After
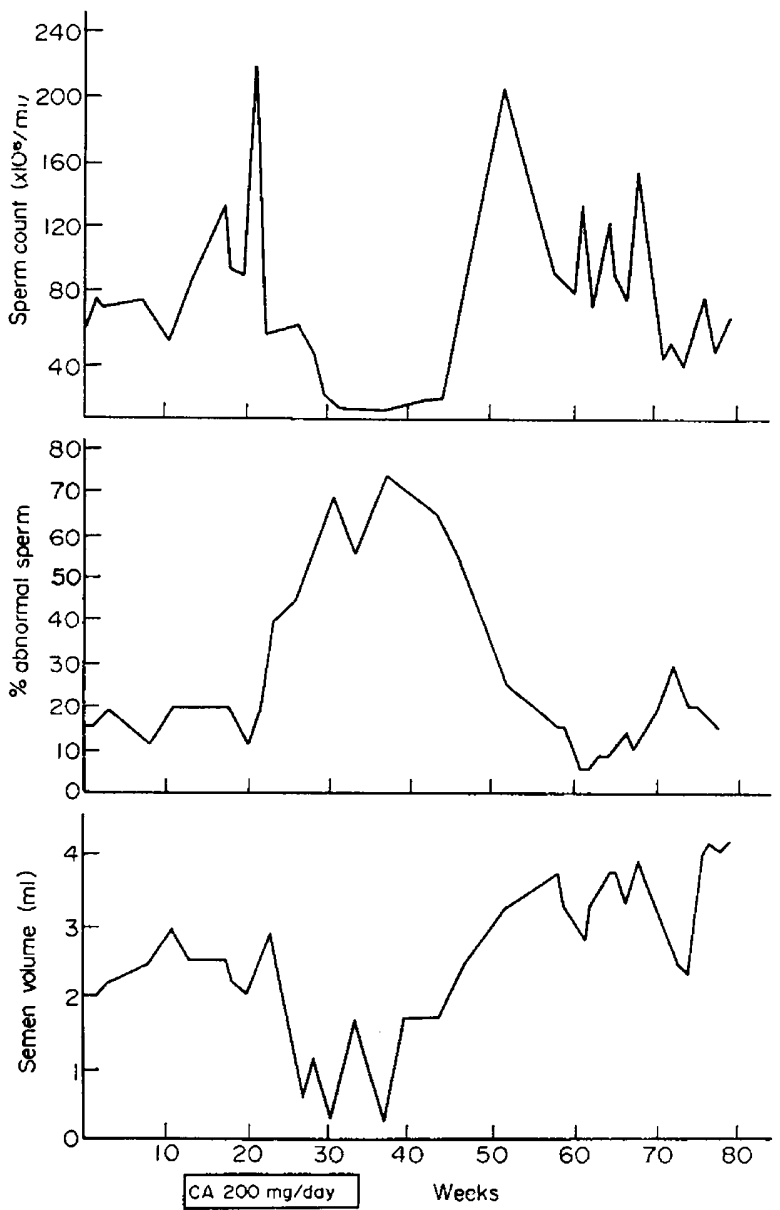

TEXT-FIG. 1. Sperm counts, $\%$ abnormal ejaculated spermatozoa and semen volume are shown with respect to control, GA administration and recovery periods (Subject 263). As the sperm count decreases, the \% abnormal spermatozoa increases and the semen volume decreases. 
beginning administration of CA, sperm counts fell below the control range within 5 to 12 weeks (average of 8 weeks) and reached functional sterility (below $20 \times 10^{6} / \mathrm{ml}$ ) between 7 and 17 weeks (average of 13 weeks). After cessation of CA administration, sperm counts increased to within the control range by 8 to 12 weeks (average of 10 weeks), increased to a peak above control range by 12 to 16 weeks (average of 15 weeks), and returned to within control range in 17 to 27 weeks (average of 21 weeks). Motility decreased and later increased in consonance with the changes in sperm count. Five of the six subjects' sperm concentrations dropped to less than $1 \times 10^{6} / \mathrm{ml}$, while two of these (Subjects 291 and 308) produced azoospermic ejaculates. The sixth subject (290) was probably also azoospermic, but was unable to submit specimens during this critical period due to temporary impotence.

In addition to a marked decrease in sperm concentration, the percentage of morphologically abnormal spermatozoa was greatly increased during CA administration (Text-fig. 1). In five out of six subjects (critical specimens unavailable for Subject 290), the percentage of abnormal spermatozoa increased from values averaging about $15 \%$ during the control period to about $80 \%$ during CA administration (100\% abnormal spermatozoa was not uncommon). Therefore, the number of normal spermatozoa present in ejaculates during maximal suppression of spermatogenesis was exceedingly small. Recovery of sperm concentration was accompanied by a decrease in the percentage of abnormal spermatozoa.

Mean ejaculate volumes in control, administration and recovery periods for four men were $2.9,1.5$ and $2.6 \mathrm{ml}$, respectively, showing a reduction of about $50 \%$ followed by an essentially complete return to normal. The difference between the mean volumes of seminal fluid collected during periods of control and administration, is statistically significant (Student's $t$ test, $P<0.005$ ). There is no statistically significant difference between the control and recovery period volume $(P>0 \cdot 1)$. Data from the other two men were deleted because few recovery samples were available. Text-figure 1 shows typical changes in seminal fluid volume during and after CA administration.

\section{Effect on testicular histology}

Data combined from all six subjects show that, during maximal effect from CA, the numbers of spermatogonia were reduced by $20 \%$, spermatocytes by $35 \%$, early spermatids by $71 \%$ and late spermatids by $82 \%$ (Table 1 ). Abnormal spermatocytes and spermatids increased with administration as follows: spermatocytes, from near zero to $40 \%$; early spermatids from $1 \%$ to $7.5 \%$; late spermatids, from $11 \%$ to $33 \%$. No striking change in numbers of abnormal spermatogonia was found.

The three recovery biopsies available were taken 10 months (Subjects 263 and 308) and $6 \frac{1}{2}$ months (Subject 246) after cessation of CA administration. These biopsies, compared with corresponding control biopsies, generally showed control levels of spermatogonia, slightly reduced levels of spermatocytes and late spermatids, and slightly greater than control levels of early spermatids (Table 2). Both early and late spermatid numbers were markedly increased over administration values. The histogram of germ cell quantification for one 
H. C. Morse et al.

Table 1. Effects of cyproterone acetate on the number of cells of the germinal epithelium of human testes*

\begin{tabular}{|c|c|c|c|c|}
\hline Subject & Spermatogonia & Spermatocytes & $\begin{array}{c}\text { Early } \\
\text { spermatids } \\
(S a-S b)\end{array}$ & $\begin{array}{c}\text { Late } \\
\text { spermatids } \\
(S c-S d)\end{array}$ \\
\hline $\begin{array}{l}246 \text { Control } \\
\mathrm{CA} \\
\% \text { decrease } \dagger\end{array}$ & $\begin{array}{l}1.66 \\
1.06 \\
36\end{array}$ & $\begin{array}{l}1.90 \\
1.03 \\
46\end{array}$ & $\begin{array}{l}1.57 \\
0 \\
100\end{array}$ & $\begin{array}{l}1 \cdot 83 \\
0.03 \\
98\end{array}$ \\
\hline $\begin{array}{l}263 \text { Control } \\
\text { CA } \\
\% \text { decrease }\end{array}$ & $\begin{array}{l}1 \cdot 15 \\
11 \cdot 02\end{array}$ & $\begin{array}{l}1 \cdot 68 \\
1 \cdot 21 \\
28\end{array}$ & $\begin{array}{l}2 \cdot 21 \\
0 \cdot 60 \\
73\end{array}$ & $\begin{array}{l}2 \cdot 26 \\
0 \cdot 50 \\
78\end{array}$ \\
\hline $\begin{array}{l}290 \text { Control } \\
\mathrm{GA} \\
\% \text { decrease }\end{array}$ & $\begin{array}{l}1 \cdot 70 \\
1 \cdot 48 \\
13\end{array}$ & $\begin{array}{l}1.45 \\
1 \cdot 36 \\
6\end{array}$ & $\begin{array}{l}1.95 \\
1 \cdot 19 \\
39\end{array}$ & $\begin{array}{l}1.45 \\
0.45 \\
69\end{array}$ \\
\hline $\begin{array}{l}291 \text { Control } \\
\mathrm{CA} \\
\% \text { decrease }\end{array}$ & $\begin{array}{l}1 \cdot 66 \\
1 \cdot 22 \\
27\end{array}$ & $\begin{array}{l}1.69 \\
0.65 \\
62\end{array}$ & $\begin{array}{l}1.61 \\
0.005 \\
\sim 100\end{array}$ & $\begin{array}{l}1 \cdot 53 \\
0 \\
100\end{array}$ \\
\hline $\begin{array}{l}296 \text { Control } \\
\mathrm{CA} \\
\% \text { decrease }\end{array}$ & $\begin{array}{l}2 \cdot 17 \\
1.84 \\
15\end{array}$ & $\begin{array}{l}3 \cdot 96 \\
2 \cdot 23 \\
44\end{array}$ & $\begin{array}{l}4 \cdot 60 \\
1 \cdot 86 \\
60\end{array}$ & $\begin{array}{l}3 \cdot 10 \\
0 \cdot 98 \\
68\end{array}$ \\
\hline $\begin{array}{l}308 \text { Control } \\
\text { CA } \\
\% \text { decrease }\end{array}$ & $\begin{array}{l}1 \cdot 74 \\
1 \cdot 48 \\
15\end{array}$ & $\begin{array}{l}2 \cdot 00 \\
1 \cdot 74 \\
13\end{array}$ & $\begin{array}{l}1 \cdot 78 \\
0.35 \\
80\end{array}$ & $\begin{array}{l}1 \cdot 61 \\
0 \cdot 18 \\
89\end{array}$ \\
\hline $\begin{array}{l}\text { Average control } \\
\text { Average CA } \\
\text { Average } \% \text { decrease } \ddagger\end{array}$ & $\begin{array}{l}1.68 \\
1.35 \\
20\end{array}$ & $\begin{array}{l}2 \cdot 11 \\
1 \cdot 37 \\
35\end{array}$ & $\begin{array}{l}2 \cdot 28 \\
0 \cdot 67 \\
71\end{array}$ & $\begin{array}{l}1.96 \\
0 \cdot 36 \\
82\end{array}$ \\
\hline
\end{tabular}

* Numbers expressed as the Sertoli cell ratio (number of a cell type/number of Sertoli cells).

$\dagger \frac{\text { Experimental value-Control value }}{\text { Control value }} \times 100$.

$\$$ Average experimental value - Average control value Average control value

Table 2. Recovery of germinal cells in human testes after discontinuing administration of cyproterone acetate*

\begin{tabular}{|c|c|c|c|c|}
\hline Subject & Spermatogonia & Spermatocytes & $\begin{array}{c}\text { Early } \\
\text { spermatids } \\
(S a-S b)\end{array}$ & $\begin{array}{c}\text { Late } \\
\text { spermatids } \\
(S c \longrightarrow S d)\end{array}$ \\
\hline $\begin{array}{l}246 \text { Control } \\
\text { Recovery } \\
\% \text { difference } \dagger\end{array}$ & $\begin{array}{l}1 \cdot 66 \\
1 \cdot 51 \\
\downarrow 9\end{array}$ & $\begin{array}{l}1.90 \\
1.68\end{array}$ & $\begin{array}{l}1.57 \\
\uparrow .30 \\
\uparrow 46\end{array}$ & $\begin{array}{l}1 \cdot 83 \\
1 \cdot 10 \\
\downarrow 40\end{array}$ \\
\hline $\begin{array}{l}263 \text { Control } \\
\text { Recovery } \\
\text { \% difference }\end{array}$ & $\begin{array}{l}1 \cdot 15 \\
\uparrow 2\end{array}$ & $\begin{array}{l}1.68 \\
\downarrow 21\end{array}$ & $\begin{aligned} 2 \cdot 21 \\
1 \cdot 82 \\
\downarrow 18\end{aligned}$ & $\begin{array}{l}2.26 \\
153\end{array}$ \\
\hline $\begin{array}{l}308 \text { Control } \\
\text { Recovery } \\
\% \text { difference }\end{array}$ & $\begin{array}{l}1.74 \\
1.67 \\
14\end{array}$ & $\begin{aligned} 2.00 \\
1.56 \\
\downarrow 22\end{aligned}$ & $\begin{array}{r}1 \cdot 78 \\
3 \cdot 23 \\
\uparrow 81\end{array}$ & $\begin{array}{c}1.61 \\
1.96\end{array}$ \\
\hline $\begin{array}{l}\text { Average control } \\
\text { Average recovery } \\
\text { Average } \% \text { difference } \ddagger\end{array}$ & $\begin{array}{l}1.52 \\
1.45 \\
\downarrow 5\end{array}$ & $\begin{array}{l}1.86 \\
\downarrow 18\end{array}$ & ${ }_{\uparrow 32} 2 \cdot 45$ & $\begin{array}{l}1.90 \\
1.37\end{array}$ \\
\hline
\end{tabular}

* Numbers expressed as the Sertoli cell ratio (number of a cell type/number of Sertoli cells).

$\dagger \frac{\text { Recovery value - Control value }}{\text { Control value }} \times 100 ; \uparrow=$ increase; $\downarrow=$ decrease.

$\ddagger$ Average recovery value-Average control value $\times 100$. Average control value 
subject (246) for control, administration and recovery biopsies shown in Textfig. 2 is typical for the whole group. The histological appearance of biopsies from these three periods are shown in Plate 1.

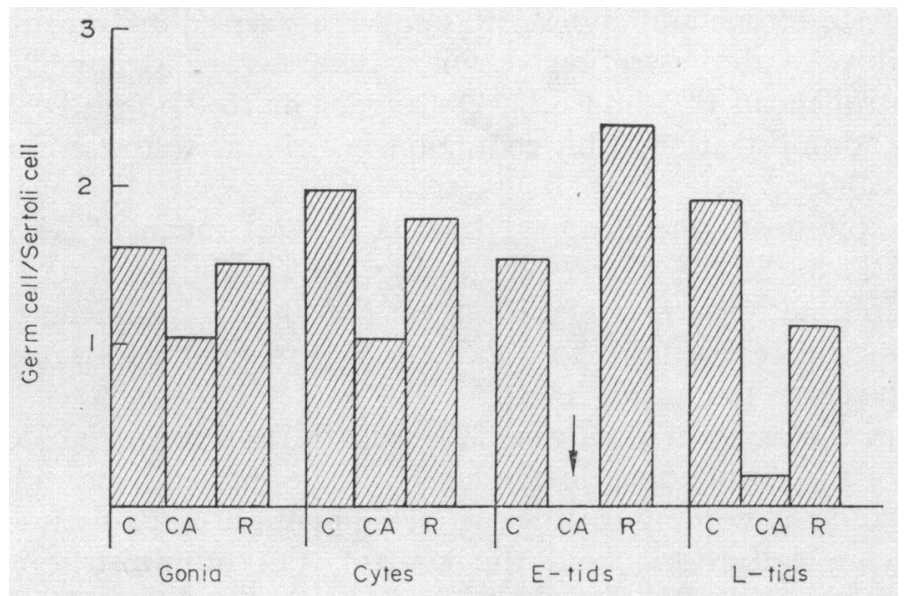

Text-Fig. 2. Sertoli cell ratios of spermatogonia (gonia), spermatocytes (cytes), early spermatids (E-tids) and late spermatids (L-tids) during control (C), cyproterone acetate administration (CA) and recovery (R) periods (Subject 246).

Subjective examination of the Leydig cells of all biopsies showed no obvious changes in morphology or number, although a slight ruffling of nuclear membranes was noted in Leydig cells in three out of six of the administration biopsies. Control and administration biopsies for Subject 246 were quantified with the following results: control $0 \cdot 15 \pm$ S.D. $0 \cdot 05$, administration $0 \cdot 16 \pm$ S.D. $0 \cdot 03$. Evaluation with Student's $t$ test indicated that no significant change in Leydig cell number occurred $(P>0 \cdot 3)$.

\section{Effect on plasma hormone levels}

Plasma testosterone was measured in each of the six subjects. Their mean control value and standard deviation was $556 \cdot 3 \pm 157 \cdot 1 \mathrm{ng} / 100 \mathrm{ml}$. During CA administration, there was a significant drop in plasma testosterone to $329.8 \pm$ $194.6 \mathrm{ng} / 100 \mathrm{ml}(P=0.05)$. Postadministration values returned to control levels $(548 \pm 170.5 \mathrm{ng} / 100 \mathrm{ml})$.

Plasma FSH was measured in each of the six subjects. Their control mean was $32 \cdot 6 \pm$ S.D. $3 \cdot 1 \mu \mathrm{g}$ standard $/ 100 \mathrm{ml}$ (radioimmunoassay; LER-907-standard). No statistically significant difference $(P \leqslant 0.05)$ was found between the control values, the CA administration values (32.9 \pm S.D. $4 \cdot 1 \mu \mathrm{g}$ LER-907/100 ml) and postadministration values $(32.3 \pm$ S.D. $0.9 \mu \mathrm{g}$ LER-907/100 ml). (Normal control range, 22.0 to $45.3 \mu \mathrm{g}$ LER-907/100 ml; mean $=34.2 \pm$ S.D. $8.6 \mu \mathrm{g}$ LER-907/100 ml.)

Plasma ICSH was measured in each of the six subjects. Their control mean was $7 \cdot 6 \pm$ S.D. $2 \cdot 2 \mu \mathrm{g}$ LER-907/100 ml. No statistically significant difference $(P \leqslant 0.05)$ was found between CA administration values $(7.5 \pm$ S.D. $3.4 \mu \mathrm{g}$ LER-907/100 ml) and postadministration values (7.9 \pm S.D. $1.9 \mu$ g LER-907/ 
$100 \mathrm{ml}$ ). (Normal control range, $4 \cdot 7$ to $15 \cdot 3 \mu \mathrm{g}$ LER-907/100 $\mathrm{ml} ;$ mean $=9 \cdot 0 \pm$ S.D. $2 \cdot 6 \mu$ g LER-907/100 ml).

\section{Effect on urinary hormone excretion}

Urinary testosterone and epitestosterone were assessed in four subjects during control and CA administration. Urinary testosterone dropped significantly from a control mean of $73.8 \pm$ S.D. $20 \cdot 8 \mu \mathrm{g} / 24 \mathrm{hr}$ to $21 \cdot 5 \pm$ S.D. $8 \cdot 1 \mu \mathrm{g} / 24 \mathrm{hr}$ during CA administration. This reduction in urinary testosterone was significant at $P=0.005$.

Urinary epitestosterone dropped from a control mean of $54 \cdot 5 \pm$ S.D. $32 \cdot 6$ $\mu \mathrm{g} / 24 \mathrm{hr}$ to $11 \cdot 8 \pm$ S.D. $4.5 \mu \mathrm{g} / 24 \mathrm{hr}$ during CA administration. This decrease in urinary epitestosterone was significant at $P=0 \cdot 025$. Insufficient postadministration values were available to obtain valid statistical results; however, they appeared to return to control levels.

Data from the assay of FSH and ICSH in thirty-seven urine collections, in which two or more unknown dosage levels were obtained, were tested using an IBM 7040 and the computer program of Thorslund \& Paulsen (1963). Data included urine collections from the control, CA administration and postadministration periods. The $F$ ratios of variation between preparations and due to parallelism and linearity were used to determine the acceptability of the assay. The lambdas $(\lambda)$ of the assays ranged from 0.073 to 0.124 with a mean of 0.094 . All other values were obtained from the interpolation tables.

Measuring urinary ICSH revealed no significant difference between control values $(0.91 \pm$ S.D. $0.44 \mathrm{mg} \mathrm{P}-26 \mathrm{e} / 24 \mathrm{hr})$ and $\mathrm{CA}$ administration values $(0.72 \pm$ S.D. $0.51 \mathrm{mg}$ P-26e/24 hr $)(P \leqslant 0.05)$. Insufficient postadministration values were available to obtain valid statistical results. With those values obtained, however, there appeared subjectively to be no difference as they fell within the subjects' control ranges.

Urinary FSH values for both control and administration periods were quite variable, but detectable in all samples. The values all fell within the normal control range for our laboratory $(0.02$ to $0.22 \mathrm{mg} \mathrm{P}-26 \mathrm{e} / 24 \mathrm{hr})$.

\section{Clinical observations}

Tests for liver or kidney function during CA administration revealed normal values. However, the $\mathrm{pH}$ of urine in four subjects changed from slightly acidic to neutral and two of these subjects reported two to three episodes of nocturia. Of the four subjects in whom blood cytology was performed, all showed a slight increase in lymphocytes but no other irregularities. An increase in the white

\section{EXPLANATION OF PLATE 1}

Photomicrographs of sections of testicular biopsies taken at three different times (Subject 263). Cleland's fixative, Fe-H and E stain. Seminiferous tubule (T); Leydig cells (L); Sertoli cell nucleus $(\mathrm{S}) . \times 280$.

Frg. 1. Preadministration biopsy.

Fig. 2. Biopsy after $3 \frac{1}{2}$ months on GA. Seminiferous epithelium is reduced to Sertoli cells and a few germ cells. Many spermatocytes and early spermatids are sloughed into the lumen. Leydig cells appear to be normal.

Fig. 3. Recovery biopsy taken 10 months after cessation of CA. Germinal epithelium and Leydig cells appear to be normal. 

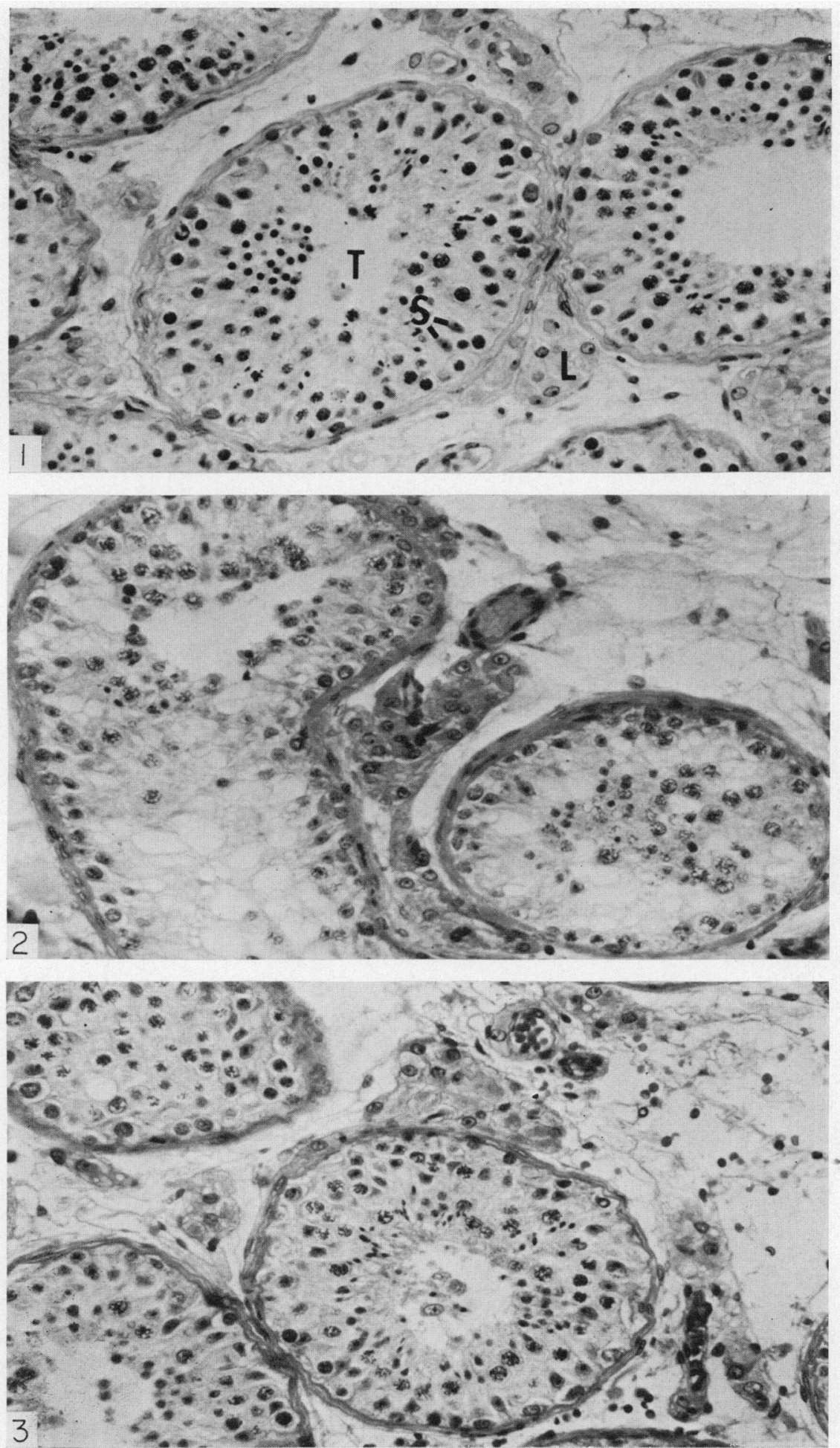

(Facing p. 372) 
blood cell content of the semen was observed in four out of six of the subjects.

Information about effects on libido and potency was obtained through repeated confidential discussions with the subjects. Reduction of libido was reported within 1 to 4 weeks and was completely lost within 10 to 14 weeks following the beginning of administration. Potency was reduced in all subjects and almost completely lost in four within 10 to 14 weeks after starting CA. Difficulties in achieving orgasm during maximum CA effect are well attested to by the paucity of seminal fluid samples submitted during this period. After administration ceased, libido and potency were reported to reappear in 1 to 2 weeks (one subject reported an increase in 1 day) and were up to control levels in 2 to 4 weeks.

The subjects denied any changes in personality or emotions. One subject lost about $10 \mathrm{lb}$, two gained 10 to $15 \mathrm{lb}$, while three remained steady during treatment. The single instance of weight loss was associated with cessation of strenuous excercise. After CA was discontinued, gynaecomastia of the small, plaque-like form was found in two subjects. One (263) reported some tenderness and swelling on both sides 1 week after administration ceased, while the other (291) had slight gynaecomastia on one side 4 months after CA was stopped.

\section{DISCUSSION}

Data from the six male subjects cooperating in this study show that $200 \mathrm{mg}$ GA/day causes a moderate decrease in semen volume, testicular germ cell number, and plasma and urinary testosterone levels and a dramatic decrease in sperm count, libido and potency. No significant change was seen in plasma or urinary ICSH and FSH levels or in Leydig cell morphology or numbers.

The striking decrease in germ cell numbers in the germinal epithelium of the testis during CA administration indicates that the major site of inhibition is in the testis rather than in the epididymis or remaining ductular system. Germ cell numbers were reduced most strikingly as they became more mature. Defects incurred in spermatogonia might cause death immediately or later in development as they become spermatocytes or spermatids. It is of interest that this pattern of depletion is similar to that caused by testosterone enanthate administration (Heller, Morse, Su \& Rowley, 1970). Possible causes for this reduction in spermatogenesis will be discussed later.

In view of the reduction of all major germ cell types, one would also expect an increase in FSH, as occurs, for example, after depletion of germ cells by radiation (G. G. Heller, unpublished data). The fact that such an increase was not detected is reminiscent of the failure of FSH to increase during germ cell depletion caused by testosterone treatment (Heller et al., 1970). It is possible that the considerable numbers of spermatogonia and spermatocytes remaining during CA administration ( $85 \%$ and $65 \%$ of control, respectively) may be sufficient to keep FSH levels in the control range. On the other hand, the progestational activity of CA may be balancing the tendency for increase in FSH by partial central inhibition. Schoonees, Schalch \& Murphy (1971) have reported a transient decrease in plasma FSH in men suffering from prostatic carcinoma who were given $200 \mathrm{mg} \mathrm{CA} /$ day, while Vosbeck \& Keller (1971), 
using the same dose, have shown a reduction in urinary FSH in some of their normal male subjects.

The lack of change in numbers or morphology in Leydig cells is consonant with our finding that ICSH levels remain unchanged during CA administration. There have been reports of changes in human Leydig cells (Markewitz et al., 1969; Stadtler, Horn \& Moormann, 1971), but the lack of change in ICSH has been commonly found (Geller, Baron, Warburton \& Loh, 1969; Schoonees et al., 1971; Walsh, Swerdloff \& Odell, 1971). In spite of this lack of change in ICSH, we have detected a decrease in plasma and urinary testosterone during CA administration. This finding has been confirmed by several other workers (Scott \& Schirmer, 1966; Geller, Fruchtman, Newman, Roberts \& Silva, 1967; Geller et al., 1968; Scott \& Wade, 1969; Geller et al., 1969; Schoonees et al., 1971).

The possibility exists that CA could cause a change in plasma testosterone level by a change in kidney function or a reduction in binding by testosteronebinding globulin causing an increase in metabolic clearance rate. This is unlikely in view of the fact that a decrease in urinary testosterone was also detected in this study and by Geller et al. (1969). In addition, they also found that injected testosterone propionate was excreted by men in the same quantities with or without simultaneous CA administration, and that CA inhibited the increase in testosterone excretion stimulated by HCG. In view of this evidence, we concluded that CA may be causing an inhibition of testosterone secretion, either directly or by some indirect means other than ICSH reduction.

It has been demonstrated that cyproterone (free alcohol form) can inhibit testosterone synthesis in rat testis microsomes (Breuer \& Hoffman, 1968) but this has not been shown in the human or for the distinctly different CA (acetate form). Cyproterone in the free alcohol form also presents the enigma of causing an increase in testosterone levels in men without causing any significant increase in total gonadotrophins (Apostolakis, Tamm \& Voigt, 1968; RauschStroomann, Petry, Hocevar, Mauss \& Senge, 1970). Clarification of the direct effects of cyproterone (free alcohol form) and CA on human Leydig cell function await studies on testosterone synthesis in vitro by testicular biopsies.

The reduction in libido, potency, sperm concentration and semen volume (a measure of accessory organ function) could all be caused by androgen deprivation. The major cause of deprivation might be brought about by a competition between CA and androgens for binding-sites in androgen-dependent tissues. This effect would be increased by the concomitant reduction in testosterone level. It could be conjectured, however, that the reduced testosterone level alone might be sufficient to account for these changes without any antiandrogenic effect. Data are lacking to show the level of testosterone which is sufficient to maintain masculinization in normal men.

The germinal epithelium is known to require both testosterone and FSH to carry out normal spermatogenesis (Heller, Lalli \& Rowley, 1968). With no change in FSH, the lack must be presumed to concern the availability of testosterone or possibly a direct 'poisoning' effect from CA or its metabolites. Such an effect has been suggested for progesterone (Heller, Moore, Paulsen, Nelson \& Laidlaw, 1959) and for clomiphene citrate (Heller \& Heller, 1970). The 
demonstrated effect of $\mathrm{CA}$ on the germinal epithelium does not rule out the possibility that androgen deprivation, possibly in the epididymis, could inhibit sperm maturation and thereby further reduce sperm concentration in the seminal fluid.

An antiandrogen has been defined as 'a blocking agent of androgen receptors' (Neumann et al., 1967). This term is not meant to include agents which induce testicular atrophy and/or reduction of testosterone production primarily by virtue of their ability to inhibit gonadotrophin secretion or by directly inhibiting testosterone synthesis. It is possible, however, that antiandrogen activity could cause a reduction in testosterone synthesis by enzyme inhibition.

Several investigators have shown in the rat that CA, acting either in vivo or in vitro, reduces the ability of androgen-dependent tissues to bind radioactivity from $\left[{ }^{3} \mathrm{H}\right]$ testosterone (Woolman \& Hamilton, 1968; Whalen \& Luttage, 1969; Stern \& Eisenfeld, 1969; Geller et al., 1969; Fang \& Liao, 1969; Walsh \& Korenman, 1970). In man, however, few experiments have been carried out to elucidate the mode of CA action on target organs. Jonsson (1969) incubated slices of human hypertrophied prostate and $\left[{ }^{3} \mathrm{H}\right]$ testosterone, with and without CA. Slices which were then simply blotted, digested and counted showed no change in ${ }^{3} \mathrm{H}$ uptake with the addition of CA. However, if the slices were washed for $1 \mathrm{hr}$ with steroid-free medium, there was a suggestion of a reduction in retained ${ }^{3} \mathrm{H}$ in slices incubated with CA.

Hansson \& Tveter (1971), using benign nodular hyperplastic prostate, but employing cyproterone (free alcohol form), showed a decrease in androgenbinding by slices, as well as cytosol or nuclear fractions. This again emphasizes the importance of differentiating between the free alcohol form of cyproterone and CA. As yet, there appears to be no firm evidence that CA is indeed competing with androgens for target-organ-binding sites (i.e. that $\mathrm{CA}$ is acting as an antiandrogen) in human tissue. In spite of this lack of direct evidence, it seems most likely that the observed decline in libido, potency, sperm concentration and seminal fluid volume are caused by a combined effect of the reduction in circulating testosterone and a competitive inhibition for receptor sites by GA.

The striking reduction in sperm concentration in ejaculates which were also reduced in volume indicates that CA is indeed a powerful antifertility agent in normal men. At the dose we employed, the loss of libido and potency was severe, although some of the subjects were able to supply semen specimens throughout the entire administration period. It is possible that this undesirable effect may be abolished by use of a smaller dosage which may still inhibit spermatogenesis. In this event, CA could be a candidate for use as a male contraceptive.

\section{ACKNOWLEDGMENTS}

We wish to thank Dr Martin Friedrichs, of Berlin Laboratories, New York, an affiliate of Schering AG, Berlin, Germany, for kindly supplying the cyproterone acetate. We thank Mrs Carole Marty, Mr Mike Su and Mr Neil Horike for their technical assistance. 
This investigation was supported by funds from The Ford Foundation (No. 68-0806) and The Population Council (No. M67.122), and was presented in part at the 53rd Annual Meeting of The Endocrine Society, San Francisco, California, 24th to 26th June 1971.

\section{REFERENCES}

Albert, A. (1955) Procedure for routine clinical determination of urinary gonadotropin. Proc. Staff Meet. Mayo Clin. 30, 552.

Apostolakis, M., TAMm, J. \& Voigt, K. D. (1968) The effects of HCG in cyproterone treated male subjects. In: Testosterone, Proceedings of the Workshop Conference, April 20-22, 1967, at Tremsbuttel, p. 156. Ed. J. Tamm. Georg Thieme, Stuttgart.

BEACH, F. A. \& WESTBROOK, W. H. (1968) Morphological and behavioural effects of an 'antiandrogen' in male rats. 7 . Endocr. 42,379 .

Breuer, H. \& Hoffman, W. (1968) Effect of cyproterone on the biogenesis of testerone and related compounds. In: Testosterone, Proceedings of the Workshop Conference, April 20-22, 1967, at Tremsbuttel, p. 162. Ed. J. Tamm. Georg Thieme, Stuttgart.

BRIDGe, R. W. \& ScotT, W. W. (1964) A new antiandrogen: SH714. Investve Urol. 2, 99.

Brusca, D. R., Kastella, J. M. \& Heller, G. G. (1966) Urinary testosterone excretion as an index of testicular secretion. Proc. U.S. Endocr. Soc. Chicago, p. 142. Abstract. Eds. F. G. Hofman and N. P. Christy. J. P. Lippincott, Philadelphia, Penn.

Glermont, Y. (1963) The cycle of the seminiferous epithelium in man. Am. F. Anat. 112, 35.

EDWARDs, D. A. (1970) Effects of cyproterone acetate on aggressive behaviour and the seminal vesicles of male mice. F. Endocr. 46, 477.

FANG, S. \& LiaO, S. (1969) Antagonistic action of antiandrogens on the formation of a specific dihydrotestosterone-receptor protein complex in rat ventral prostate. Molec. Pharmacol. 5, 420.

Geller, J., Baron, A., Warburton, V. \& Loh, A. (1969) The effects of progestational agents on male gonadal and pituitary function. (Abstract). Ann. intern. Med. 70, 1062.

Geller, J., Fruchtman, B., Newman, H., Roberts, T. \& Silva, R. (1967) Effect of progestational agents on carcinoma of the prostate. Cancer Chemother. Rep. 51, 41 .

Geller, J., Vazakas, G., Fruchtman, B., Newman, H., Nakao, K. \& Loh, A. (1968) The effect of cyproterone acetate on advanced carcinoma of the prostate. Surgery Gynec. Obstet. 127, 748.

Goslar, H. G., Mehring, M. \& Neumann, F. (1970) Einfluss der Antiandrogene Cyproteron und Cyproteronacetat auf das Enzymmuster im Hoden juveniler und erwachsener Ratten. Histochemie, 23, 51 .

Greep, R. O., Van Dyke, H. B. \& Chow, B. F. (1941) Use of the anterior lobe of the prostate gland in the assay of metakentrin. Proc. Soc. exp. Biol. Med. 46, 644.

Hamada, H., Neumann, F. \& Junkmann, K. (1963) Intrauterine influencing of rat fetuses by a potent progestational steroid. Acta endocr., Copenh. 44, 380.

Hansson, V. \& TVETER, K. J. (1971) Effects of anti-androgens on the uptake and binding of androgen by human benign nodular prostatic hyperplasia in vitro. Acta endocr., Copenh. 68, 69.

Heinert, G. \& TAUBERT, H.-D. (1971) Karyo-metrische und histometrische Untersuchungen an Rattenhoden nach Behandlung mit Cyproteron und Cyproteronacetat. Acta endocr., Copenh. Suppl. 152, 38.

Helier, C. G. \& Clermont, Y. (1964) Kinetics of the germinal epithelium in man. Recent Prog. Horm. Res. 20, 545.

Heller, G. G., Lalli, M. F., Pearson, J. \& Leach, D. R. (1971) A method for the quantification of Leydig cells in man. F. Reprod. Fert. 25, 177.

Heller, G. G., Lalli, M. F. \& Rowley, M. J. (1968) Factors affecting the testicular function in man. In: Pharmacology of Reproduction, 2, 61. Ed. E. Diczfalusy. Pergamon Press, Oxford.

Heller, C. G., Moore, D. J., Paulsen, C. A., Nelson, W. O. \& Laidlaw, W. M. (1959) Effects of progesterone and synthetic progestins on the reproductive physiology of normal men. Fedn Proc. Fedn Am. Socs exp. Biol. 18, 1057.

Heller, C. G., Morse, H. C., Su, M. \& Rowley, M. J. (1970) The role of FSH, ICSH and endogenous testosterone during testicular suppression by exogenous testosterone in normal men. In: Advances in Experimental Medicine and Biology, Vol. 10, The Human Testis, p. 249. Eds. E. Rosemberg and C. A. Paulsen. Plenum Press, New York.

Heller, G. V. \& Heller, G. G. (1970) Quantitation of normal and abnormal germinal cells following administration of clomiphene citrate in normal men. F. clin. Endocr. Metab. 30, 196.

Jonsson, C.-E. (1969) In vitro uptake of tritiated testosterone and oestradiol by the lateral lobe of the 
hypertrophied human prostate and the accessory sex glands of the rat-a pilot study. Acta endocr., Copenh. 61, 25.

Junkmann, K. \& Neumann, F. (1964) Mechanism of action of progestagens having an antimasculine effect on fetuses. Acta endocr., Copenh. Suppl. 90, 139.

Laschet, U., Laschet, L., Fetzner, H.-R., Glaesel, H.-V., Mall, G. \& NaAb, M. (1967) Results in the treatment of hyper- or abnormal sexuality in men with antiandrogens. (Abstract). Acta endocr., Copenh. Suppl. 119, 54.

MAcLEOD, J. (1962) A testicular response during and following severe allergic reaction. Fert. Steril. 13, 531 .

Markewitz, M., Veenema, R. J., Fingerhut, B., Nehme-Haily, D. \& Sommers, S. C. (1969) Cyproterone acetate (SH714) effect on histology and nucleic acid synthesis in the testis of patients with prostatic carcinoma. Investve Urol. 6, 638 .

Murphy, B. E. O. (1970) Methodological problems in competitive protein binding techniques: the use of Sephadex column chromatography to separate steroids. Acta endocr., Copenh. Suppl. 147, 37.

Neri, R. O., Monahan, M. D., Meyer, J. G., Aronso, B. A. \& Tabachnick, I. A. (1967) Biological studies on an anti-androgen (SH 714). Eur. F. Pharmac. 1, 438.

Neumann, F. \& von BerswordT-WALlRABE, R. (1966) Effects of a new androgen antagonist (cyproterone acetate) steroid on the testicular structure, spermatogenesis and accessory sexual glands of testosterone-treated adult hypophysectomized rats. F. Endocr. 35, 363.

Neumann, F., von Berswordt-Wallrabe, R., Elger, W., Steinbeck, H., Hahn, J. D. \& Kramer, M. (1970) Aspects of androgen-dependent events as studied by anti-androgens. Recent Prog. Horm. Res. 26, 337.

Neumann, F. \& Elger, W. (1966a) Permanent changes in gonadal function and sexual behaviour as a result of early feminization of male rats by treatment with an antiandrogen. Endokrinologie, 50, 209.

Neumann, F. \& Elger, W. (1966b) The effect of a new antiandrogenic steroid, 6-chloro-12-hydroxy-1 $\alpha$, $2 \alpha$-methylenepregna-4, 6-diene-3, 20 dione acetate (cyproterone acetate) on the sebaceous glands of mice. $\mathcal{F}$. invest. Derm. 46, 561.

Neumans, F., Elger, W. \& von Berswordt-Wallrabe, R. (1967) Intersexuality of male foetuses and inhibition of androgenic function in adult animals with a testosterone blocker. Germ. med. Mon. $12,182$.

Neumann, F., Elger, W., von Berswordt-Wallrabe, R. \& Kramer, M. (1966) Effect of regulatory mechanisms on the pituitary-diencephalic system by blocking of the central androgen receptors with a highly active androgen. Naunyn-Schmiedebergs Arch. exp. Path. Pharmak. 255, 236.

Neumann, F., Elger, W. \& Kramer, M. (1966) The development of a vagina in male rats by inhibiting the androgen receptors with an anti-androgen during the critical phase of organogenesis. Endocrinology, 78, 628 .

Neumann, F., Elger, W., Steinbeck, H. \& von Berswordt-Wallrabe, R. (1968) Antiandrogene, p. 78, In: Das Testosteron. Die Struma, 13. Symp. der Dtn Gesellshaft für Endokrinol. Würzburg, 2-4 Marz 1967.

Neumann, F., Richter, K.-D. \& Guenzel, P. (1965) Action of anti-androgens. Zentbl. VetMed. (A), $12,171$.

Odell, W. D., Parlow, A. F., Cargille, G. M. \& Ross, G. T. (1968) Radioimmunoassay for human follicle-stimulating hormone: physiological studies. F. clin. Invest. 47, 2551.

Odell, W. D., Ross, G. T. \& RAYFord, P. L. (1967) Radioimmunoassay for luteinizing hormone in human plasma and serum. F. clin. Invest. 46, 248.

OTт, F. \& Hoffet, H. (1968) Bleinflussung von Libido, Potenz und Hodenfunktion durch Antiandrogene. Schweiz. med. Wschr, 98, 1812.

Petry, R., Mauss, J., Senge, Th. \& Rausch-Stroomann, J.-G. (1970) Über den Einfluss von Cyproteronacetat, Norethisterononanthat, und Gestonoroncaproat auf die Hypophysen-Gonadenachse beim Mann. Sympn. dt. Ges. Endokr. 16, 428.

Rausch-Stroomann, J.-G., Petry, R., Hocevar, V., Mauss, J. \& Senge, Th. (1970) Influence of an antiandrogen (cyproterone) on the gonadotrophic function of the pituitary gland, on the gonads and on metabolism in normal men. Acta endocr., Copenh. 63, 595.

Rowley, M. J. \& Heller, C. G. (1966) The testicular biopsy: surgical procedure, fixation and staining technics. Fert. Steril. 17, 177.

Rowley, M. J. \& Hzller, C. G. (1971) Quantitation of the cells of the seminiferous epithelium of the human testes employing the Sertoli cell as a constant. Z. Zellforsch. mikrosk. Anat. 115, 461.

SchooneEs, R., Schalch, D. S. \& MuRPhy, G. P. (1971) The hormonal effects of antiandrogen (SH714) treatment in man. Investue Urol. 8, 635.

Scott, W. W. \& Schirmer, H. K. A. (1966) A new oral progestational steroid effective in treating prostatic cancer. Trans. Am. Ass. genito-urin. Surg. 58, 54. 
ScotT, W. W. \& WADE, J. C. (1969) Medical treatment of benign nodular prostatic hyperplasia with cyproterone acetate. F. Urol. 101, 81.

Stadtler, F., Horn, H. J. \& Moormans, J. G. (1971) Histologische Befunde an menschlichen Hodenbiopsien unter Antiandrogen-behandlung. (Abstract). Acta endocr., Copenh. Suppl. 152, 36.

Steelman, S. L. \& Pohley, F. M. (1953) Assay of the follicle stimulating hormone based on the augmentation with human chorionic gonadotropin. Endocrinology, 53, 604.

Steinbeck, H., Mehring, M. \& Neumann, F. (1971) Comparison of the effects of cyproterone acetate and oestradiol on testicular function, accessory sexual glands and fertility in a long-term study on rats. F. Reprod. Fert. 26, 65.

StrRn, J. J. \& MURPhy, M. (1971) The effects of cyproterone acetate on the spontaneous activity and seminal vesicle weight of male rats. J. Endocr. 50, 441.

Stern, J. M. \& Eisenpeld, A. J. (1969) Androgen accumulation and binding to macromolecules in seminal vesicles: inhibition by cyproterone. Science, $\mathcal{N}$. Y. 166, 233.

Thorslund, T. \& Paulsen, G. A. (1963) A computer program for the analysis of data from "parallel line" biological assays. Endocrinology, 72, 663.

Vosbeck, K. \& Keller, P. J. (1971) The influence of antiandrogens on the excretion of FSH, LH, and 17-ketosteroids in males. Hormone Metab. Res. 3, 273.

WALSH, P. C. \& KoRENMAN, S. G. (1970) Action of antiandrogens: preservation of $5 \alpha$ reductase activity and inhibition of chromatin-dihydrotestosterone complex formation. (Abstract). Clin. Res. 18, 374.

WAlsh, P. C., Swerdloff, R. S. \& Odell, W. D. (1971) Cyproterone: effect on serum gonadotropins. (Abstract). Biol. Reprod. 5, 97.

Whalen, R. E. \& Edwards, D. A. (1969) Effects of the anti-androgen, cyproterone acetate, on the mating behavior and seminal vesicle tissue in male rats. Endocrinology, 84, 155.

Whalen, R. E. \& LutTAGe, W. G. (1969) Contraceptive properties of the anti-androgen, cyproterone acetate. Nature, Lond. 223, 633.

Woolman, A. L. \& Hamilton, J. B. (1968) Local action of the anti-androgen, cyproterone acetate, on a mammalian target organ. Endocrinology, 82, 868.

Zucker, I. (1966) Effects of an anti-androgen on the mating behaviour of male guinea-pigs and rats. F. Endocr. 35, 209. 